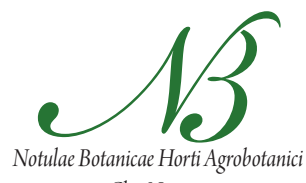

Cluj-Napoca

\title{
Studies on the Structure of Flowers and Inflorescences of Cornelian Cherry (Cornus mas L.)
}

\author{
Cevriye MERT \\ Uludag University, Faculty of Agriculture, Department of Horticulture, Görükle Campus 16059, Bursa, Turkey; cevmert@uludag.edu.tr
}

\begin{abstract}
This study reports on the arrangement of flower buds and structure of floral organs of cornelian cherry (Cornus mas L.) cultivars local to Turkey. The local cultivars were investigated under stereo microscope, light microscope, and scanning electron microscope (SEM). The results indicate that each node has two oppositely positioned buds on 1-year-old shoot. Inflorescences resembled the umbel structure that enclosed four (two sets of oppositely oriented) bud scales. The mean flower number varied between 16.3 and 19.9 per cluster among the cultivars. The flowers resembled the hermaphrodite type and one flower was found to have four rudimentary sepals, four petals, four stamens, and one pistil. The stamens were noted to be arranged around the base of the ovary. Each normal anther was observed to have two pollen-producing theca, and each theca was found to have two locules. The number of pollen grains per anther varied between 1380 and 4240 among the genotypes. The pistil was noted to have a deeply hollowed papillate stigmatic surface, and the central part of the style had conducting tissue. The ovarium part of the pistil was found to be surrounded by the nectary tissue, inferior type, and had two atropous ovules. The fruit resembled single-seeded, stone fruit type. This study is the first detailed study on the flower morphology and inflorescences of the cornelian cherry cultivars in Turkey.
\end{abstract}

Keywords: floral organs, morphology, SEM, Turkey

\section{Introduction}

Cornelian cherry (Cornus mas L.) is one of the original fruit species of the Anatolian peninsula. It is naturally distributed in mountainous areas as native plants, although some selections have been made from wild plants throughout the centuries. High-quality genotypes have been propagated by vegetative means, such as grafting, layering, and root suckers. Essentially, this fruit species is a valuable food resource, consumed as fruit juice, marmalade, jam, and may be canned. The fruits have high level of ascorbic acid, benzoic acid, and its salts (Cemeroglu, 1982). The total number of trees in Turkey is over 978,000 and the annual production is approximately 12,427 tons (TurkStat, 2012). The economic importance of crops has led to previous research on the selection of superior genotypes and determination of morphological traits (Eriş et al., 1994; Karadeniz, 1995; Pirlak and Güleryüz, 1995), on pollination and fertilization biology (Mert and Soylu, 2006a; Pirlak, 1997; Yalçinkaya and Eti, 1999), and on utilization of the fruits (Copur et al., 2003). Some basic information can be found in the literature concerning botanical characteristics and inflorescences of Cornaceae and Cornus species (Eyde, 1987; Xiang, et al., 2003; Xiang and Boufford, 2005).

The level of fruit set and yield of cornellian cherry trees has strong connection to flower characteristics and fertility (Mert and Soylu, 2006a). The authors therefore started systematic investigations of flower morphology and fertil- ity level of male and female organs of some cornelian cherry cultivars. The present study reports on the structure of the inflorescences and floral organs of six Cornus mas L. local cultivars that are local to Turkey.

\section{Materials and methods}

This study was conducted on the six local cultivars of cornelian cherry ('Değirmendere', 'Erkenci Değirmendere', 'İri Bardak,' 'Yuvarlak Bardak', 'Uzun Memeli' and 'Buğur') from Cumalıkızık village in Bursa city province, Turkey.

\section{Collection and fixation of the material}

Mature flower buds of the cultivars were collected and fixed in FAA solution (10 parts of formalin: 5 parts of glacial acetic acid: 50 parts of ethanol: 35 parts of water, by volume) (Sass, 1958).

\section{Counting and measurement of flower buds}

The length and width of the flower buds and the length of a single flower were measured using 50 samples for each cultivar. To determine the mean number of flowers per flower cluster, 100 newly opened flower buds were examined. The mean number of anthers per flower was determined on 100 opened flowers.

\section{Determination of pollen production per anther}

For this purpose, the hemocytometric method was used (Mert and Soylu, 2007). The flowers fixed in FAA so- 
54

lution were rinsed for 10 min with a $50 \%, 70 \%$, and $95 \%$ ethanol solution, and twice with a $100 \%$ ethanol solution, in series, respectively. Subsequently, 100 unshed anthers were placed in a glass vial and left at room temperature to dry and release their pollen grains. Then, $2 \mathrm{~mL}$ of distilled water were added to each glass vial. A droplet of this solution was placed on a hemocytometric glass slide and covered with a thick microscope slide cover. The pollen grains were counted using a light microscope (BH-2, Olympus Optical Co., Tokyo, Japan) in a sample of $1 \mathrm{~mm}^{3}$ chamber volume. This procedure was repeated four times for every vial.

\section{Stereo microscope observations}

The materials of flower buds fixed in FAA solution were used to determine the structure of a single flower and floral organs under a stereo microscope (SZ6045TR, Olympus Optical Co. Ltd., Tokyo, Japan). Detailed observations were made and some samples were photographed.

\section{Scanning electron microscopy}

SEM was used for observations of floral organs. Samples fixed in the FAA solution were dehydrated for $10 \mathrm{~min}$ in a 50\%, 70\%, and 95\% ethanol solution, and twice with absolute ethanol solution, in series, respectively, to the critical dry point (Mert and Soylu, 2006b). The samples were subsequently mounted on SEM stubs, coated with gold-palladium (Edwards, S150B, England), and examined with an SEM (JSM-6335F; Jeol, Tokyo, Japan).

\section{Light microscopy}

Flower samples fixed in FAA solution were washed thrice in phosphate buffer $(\mathrm{Ph}=7.2)$ for $20 \mathrm{~min}$. The samples were then fixed in $1 \%$ osmium tetroxide for 2

Tab. 1. Dimensions of the bud and a single flower of the cornelian cherry cultivars

\begin{tabular}{cccc}
\hline \multirow{2}{*}{ Cultivars } & \multirow{2}{*}{\begin{tabular}{c} 
Flower \\
\cline { 3 - 4 }
\end{tabular}} & \multicolumn{2}{c}{ Bud } \\
\cline { 3 - 4 } & length $(\mathrm{mm})$ & $\begin{array}{c}\text { Length } \\
(\mathrm{mm})\end{array}$ & $\begin{array}{c}\text { Width } \\
(\mathrm{mm})\end{array}$ \\
\hline 'Değirmendere' & 2.73 & 7.67 & 5.75 \\
\hline 'Erkenci Değirmendere' & 2.52 & 7.13 & 5.50 \\
\hline 'İri Bardak' & 2.57 & 6.11 & 5.00 \\
'Yuvarlak Bardak' & 2.50 & 6.75 & 5.13 \\
\hline 'Uzun Memeli' & 2.40 & 6.13 & 5.13 \\
\hline 'Buğur' & 2.30 & 5.90 & 4.43 \\
\hline
\end{tabular}

$h$, and washed four times in a phosphate buffer. Subsequently, the samples were dehydrated for $10 \mathrm{~min}$ in a $50 \%$, $70 \%$, and $95 \%$ ethanol solution, and twice with absolute ethanol solution, in series, respectively. The samples were gradually infiltrated and embedded in Spurr epoxy resin, and sectioned $(1 \mu \mathrm{m})$ using an ultramicrotome (Reichert Supernova, Leica, Vien, Austria) with a glass knife (Mert and Soylu, 2006b). The flower sections were stained with toluidine blue and examined under a light microscope (BH-2, Olympus Optical Co., Tokyo, Japan).

\section{Statistical Analysis}

The data were tested by one-way analysis of variance using the Minitab 14.0 software, and means were compared using Duncan's multiple range test $(p<0.05)$.

\section{Results}

\section{Flower bud arrangements}

Flower buds were located on the node of 1-year-old shoots. Every node was found to have two oppositely oriented and easily recognizable buds - either of the two might be a flower or vegetative part, or one of them might be a vegetative and the other one may be a flower bud (Fig. 1A). The flower buds were noted to be large roundish, yellowish green, having sharp tips, and covered with two sets of oppositely oriented bud scales (Fig. 1B, Tab. 1). The sizes ranged from 5.90 to $7.67 \mathrm{~mm}$ in length, and from 4.43 to $5.75 \mathrm{~mm}$ in width.

\section{Inflorescence structure}

Inflorescence structure resembled an umbel structure with many stalks of flowers (Fig. 1C). The mean number of flowers per inflorescence varied between 16.3 and 19.9 among the cultivars (Tab. 2). Flowering took place gradually. The 5-6 round flowers opened first, and then the inside central flowers opened in the cluster.

\section{Flower organs}

The flower resembled the hermaphrodite type, and had both male and female organs. The flowers were small and varied in length between 2.30 and $2.73 \mathrm{~mm}$ among the genotypes (Tab. 1). The flowers had four petals, approximately four stamens, and a single pistil. The ovarian part of the pistil was surrounded by a mound-like, bright yellow nectar disc (Fig. 2A). Pedicels were long and the surface was covered with dense hairs (Fig. 2B).

Tab. 2. Mean number of flower in a cluster, anther per flower and pollen grain per anther in the cornelian cherry cultivars

\begin{tabular}{cccc}
\hline Cultivars & Number of flower per cluster & Number of anther per flower & Number of pollen grain per anther \\
\hline 'Değirmendere' & $16.3 \pm 4.1$ & 3.96 & $4240 \mathrm{a}^{2}$ \\
'Erkenci Değirmendere' & $18.6 \pm 4.2$ & 3.22 & $2880 \mathrm{ab}$ \\
\hline 'Iri Bardak' & $16.7 \pm 4.5$ & 3.96 & $2800 \mathrm{abc}$ \\
'Yuvarlak Bardak' & $16.7 \pm 5.0$ & 3.96 & $2600 \mathrm{bc}$ \\
\hline 'Uzun Memeli' & $16.8 \pm 4.1$ & 3.92 & $3280 \mathrm{ab}$ \\
\hline 'Buğur' & $19.9 \pm 5.3$ & 3.96 & $1380 \mathrm{c}$ \\
\hline
\end{tabular}

${ }^{2}$ Mean separation in columns by Duncan's multiple range test at $P \leq 0.05$ lowercase letters 

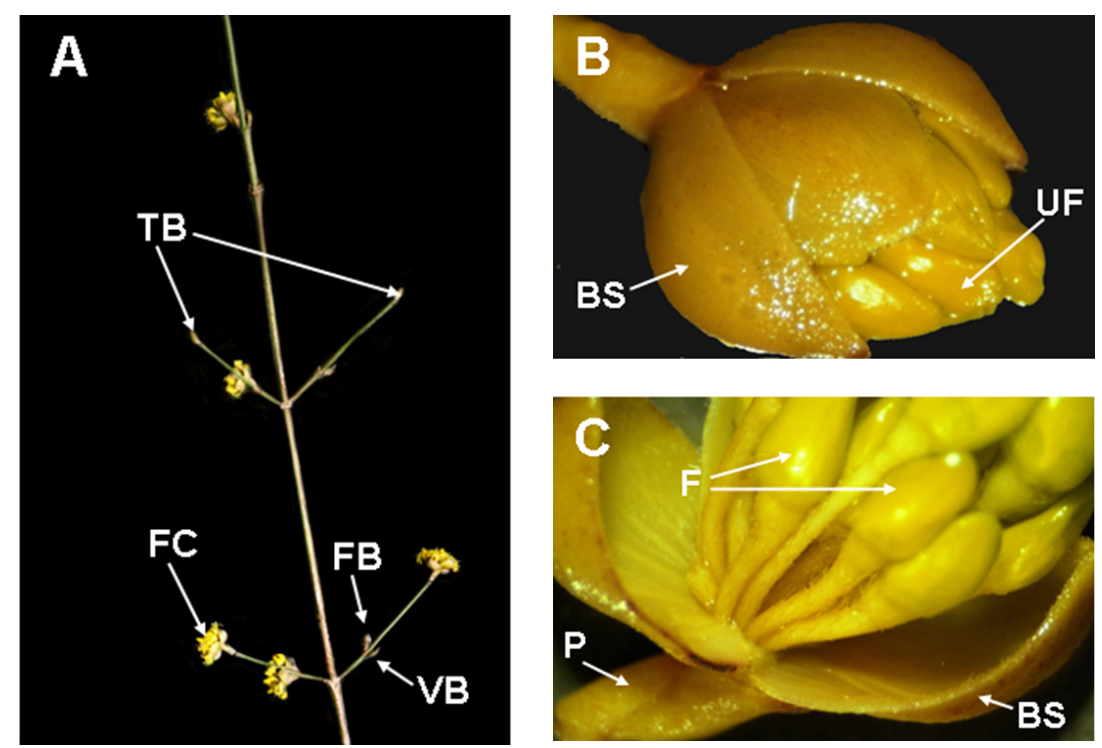

Fig. 1. Cornelian cherry flower cluster photographed with a stereo microscope. (A) Orientation of the buds on one year old shoots of cornelian cherry (Cornus mas L.). (B) Unopened flower cluster in the two sets of oppositely oriented bud scales. (C) Appearance of a flower cluster resembled the umbel structure. BS: bud scale, F: flower, FB: flower bud, FC: flower cluster, P: pedicel, TB: terminal bud, UF: unopened flowers in a cluster, VB: vegetative bud

\section{Petals and sepals}

Four bright yellow with sharp-tip petals covered the stamens and ovary before flowering and opened during flowering (Fig. 2A). The petal number was five in which the flowers had five stamens (Fig. 2C). The sepals were rudimentary and could be seen under the microscope (Fig. 2B), and had sharp tips, similar to the petals.

\section{Stamens and pollen grains}

Stamens were arranged around the base of the ovary and other floral organs, and consisted of two morphologically distinct parts - the anther and filament (Fig. 2A). The anthers were observed to have two lobes and each lobe contained two pollen sacs (Fig. 3A, B). The anther contained the reproductive and nonreproductive tissues that are responsible for producing and releasing pollen grains. The surrounding tissue of the anthers consisted of surface epidermis, endothecium, middle layers, and tapetum (Fig.
3B). The average number of anthers per flower was almost four, irrespective of the genotypes (Tab. 2). However, this number varied between three and four in some flowers (Fig. 2C). The number of pollen grains per anther varied significantly among the genotypes and ranged between 1380 and 4240 (Tab. 2).

\section{Female organ}

The ovarium represented the inferior (epigynous) type (Fig. 4A-C). The female organ had a stigmatic surface, style, and ovary part. The stigma consisted of papillate cells. These cells were shrunken, apparently to hold the attached pollen grains more easily on its surface (Fig. 5A, B). The surface of the style was covered with a uniform epidermis. Figure 5A shows the inner part and Fig. 5C presents the cells of the transmitting tissue of the style. These tissues are responsible for the capture of pollen grains and facilitation of passage of the pollen tube to the ovules. The ovary had two atropous ovules (Fig. 4C, D).
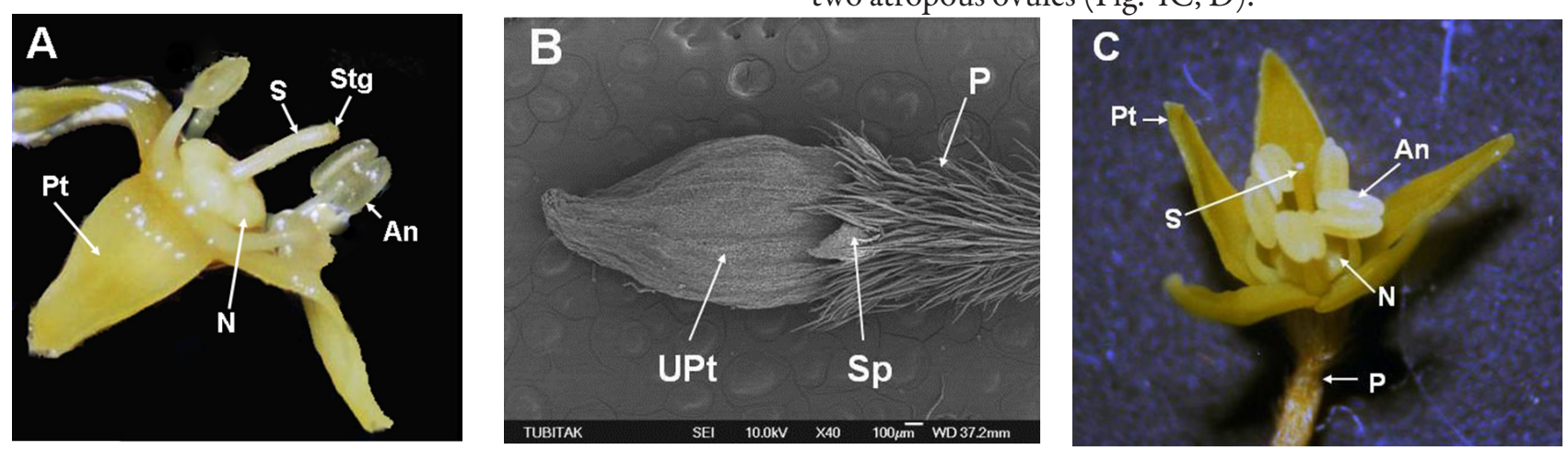

Fig. 2. (A) Appearance of an opened flower and flower organs. (B) Appearance of the petals and sepals in an unopened flower (bar $=100 \mu \mathrm{m})$. (C) Opened flower with five stamens and five petals. An: anther, N: nectary tissue, P: pedicel covered with dense hairs, Pt: petal, S: style, Sp: sepal, Stg: stigma, UPt: unopened petals 

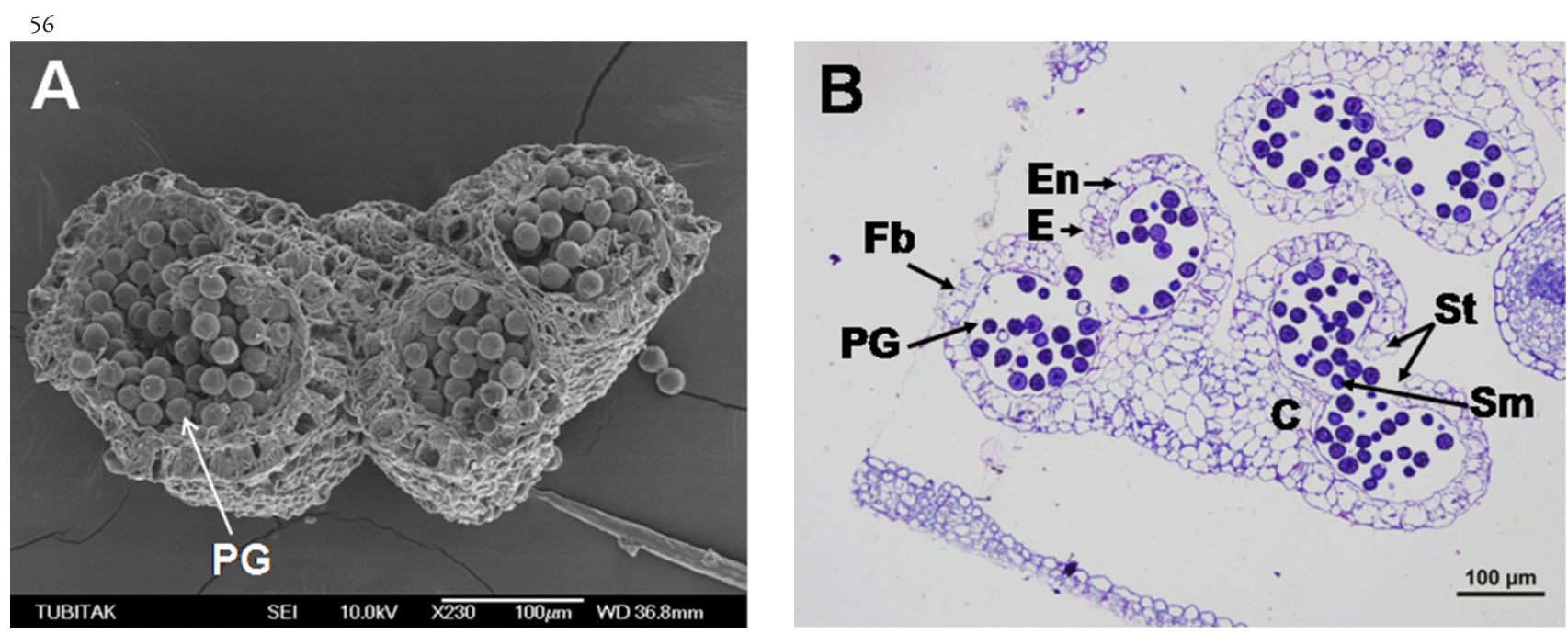

Fig. 3. (A) Scanning electron micrograph of anther lobes in Değirmendere cultivar. (B) Transverse section of four locules in Değirmendere cultivar, anther stained with toluidine blue and photographed using light microscopy. $($ bar $=100 \mu \mathrm{m})$. C: connective, E: epidermis, En: endothecium, Fb: fibrous band, PG: pollen grain, Sm: septum, St: stomium
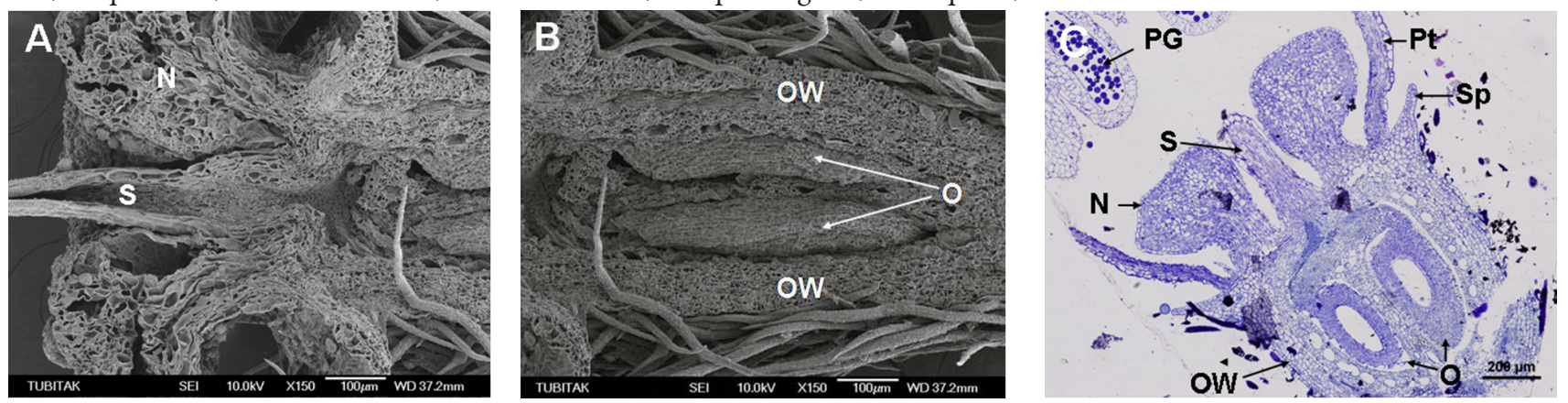

Fig. 4. (A, B) Scanning electron micrographs of the ovarium part of a single flower (bar $=100 \mu \mathrm{m})$. (C) Appearance of atropous ovules $($ bar $=200 \mu \mathrm{m})$. (D) Appearance of embryo sac $(\mathrm{bar}=100 \mu \mathrm{m})$. Longitudinal sections of ovarium stained with toluidine blue and photographed using light microscopy. EC: egg cell, ES: embryo sac, M: micropyle, N: nectary tissue, O: ovule, OW: ovarium wall, PG: pollen grain, Pt: petal, S: style, Sp: sepal
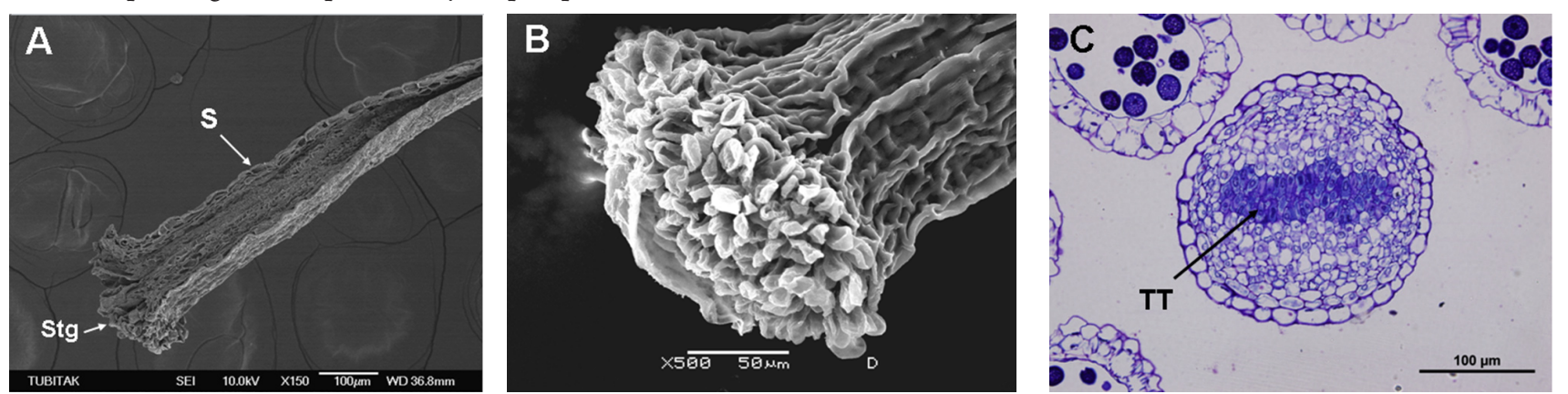

Fig. 5. (A) Scanning electron micrographs of inner part of the style (bar $=100 \mu \mathrm{m})$ and (B) stigmatic surface $(\mathrm{bar}=50 \mu \mathrm{m})$. (C) Transverse section of style stained with toluidine blue and photographed using light microscopy (bar $=100 \mu \mathrm{m})$. S: style, Stg: stigma, TT: transmitting tissue

\section{Fruit}

The fruit resembled one seeded stone type fruit, such as cherry fruit.

\section{Discussion}

The arrangement of the buds on the shoots was found to be similar to other Cornus species (Eyde, 1987). Inflorescences were enclosed with two pairs of scale-like bracts as determined in Cornus mas L. and other Cornus species (Eyde, 1987; Xiang et al., 2003).
The inflorescence was obviously an umbel, similar to the findings of previous studies in the literature (Watson and Dallwitz, 1992; Xiang and Boufford, 2005). The mean number of flowers per inflorescence $(\sim 16-20)$ is in accordance with the values (10-25) given in the literature (WFE, 2007) as well as the findings of Akçay and Yalçinkaya (2003), who found this number to be about 15-26 in selected genotypes.

Although some species of Cornus, e.g., C. volkensii are dioecious (Watson and Dallwitz, 1992), all the genotypes 
examined in this study were noted to have a hermaphrodite type of flower, similar to the previous findings (Watson and Dallwitz, 1992; Wilkinson, 1944; Xiang et al., 2003; Xiang and Boufford, 2005). The flowers were noted to be smaller than those reported in the literature (WFE, 2007).

The structure and arrangement of floral organs (sepals, petals, stamens, and pistil) were found to be similar to those of Cornus species and its genotypes previously reported in the literature (Watson and Dallwitz, 1992; Wilkinson, 1944; Xiang and Boufford, 2005).

The sepals were noted to be small and the petals were distinctly visible in their yellow colors, as determined previously in Cornus species and genotypes of C. mas (Watson and Dallwitz, 1992; Wilkinson, 1944; Xiang and Boufford, 2005; WFE, 2007).

The mean number of stamens per flower was almost four, as indicated in previous researches (Pirlak, 1997; Watson and Dallwitz, 1992; Xiang and Boufford, 2005). The number of pollen grains per anther (1380-4240) was close to the findings of Pirlak (1997), who found that this number varied between 1781 and 3417 in different genotypes of C. mas. However, there was a significant variation observed among the genotypes in this respect, and this characteristic may be an important factor in cornelian cherry orchards for obtaining good pollination and fruit set.

The ovarium part of the female organ was noted to be enclosed by the nectarious tissue (epigynous) and had two ovules, similar to that observed in the various species of Cornus (Wilkinson, 1944; Watson and Dallwitz, 1992; Xiang and Boufford, 2005). The ovules resembled the atropous type, which contrasts with the findings of Wilkinson (1944), who stated that the ovules were of the anatropous type in Cornus species, and the statement of Watson and Dallwitz (1992) concerning some of the Cornaceae species, although Watson and Dallwitz (1992) reported that the stigmatic surface was dry and was of the nonpapillate type.

As indicated in this study, European cornels have one seed (WFE, 2007). However, some species of Cornus have two or more seeds (Watson and Dallwitz, 1992; Xiang and Boufford, 2005).

\section{References}

Akçay ME, Yalçinkaya E (2003). Researces on pollination biology of some cornelian cherry (Cornus mas L.) types growing in Yalova. Türkiye IV. Ulusal Bahçe Bitkileri Kongeresi, 08-12 Eylül, Antalya, 280-281 p. (In Turkish)

Cemeroglu B (1982). Meyve Suyu Üretim Teknolojisi. Teknik Basım Sanayi Matbaası, Ankara, 309 p.

Copur OU, Soylu A, Gürbüz O, Değirmencioğlu N, Ertürk Ü (2003). Suitability of Cornus mas (Cornelian cherry) genotypes and cultivars for fruit juice. Biotechnol Biotec Eq 17:176-182.
Eriş A, Soylu A, Barut E, Dalkiliç Z (1994). A research on the selection of cornel, 207-210 p. In: Schmidt H and Kellerhals M (Eds.). Progress in Temperate Fruit Breeding. Proc of the Eucarpia Fruit Breeding Section Meeting held at Wädenswil/ Einsiedeln, August 30-September 31993.

Eyde RH (1987). The case of keeping Cornus in the broad Linnaean sense. Syst Bot 12:505-518.

Karadeniz T (1995). Investigations on selection of Cornelian cherry grown in Görele (Giresun). Bahçe 24:36-44. (In Turkish)

Mert C, Soylu A (2006a). Studies on the fertilisation biology of some Cornelian cherry (Cornus mas L.) cultivars. J Agric Fac Uludag Univ 21:45-49. (In Turkish)

Mert, C, Soylu A (2006b). Flower and stamen structures of male-fertile and male-sterile chestnut (Castanea sativa Mill.) cultivars. J Amer Soc Hort Sci 131(6):752-759.

Mert C, Soylu A (2007). Morphology and anatomy of pollen grains from male-fertile and male-sterile cultivars of chestnut (Castanea sativa Mill.). J Hort Sci Biotech 82(3):474-480.

Pirlak L, Güleryüz M (1995). A study on selection of cornelian cherry (Cornus mas L.) grown in Uzundere, Tortum and Oltu districts. Türkiye II. Ulusal Bahçe Bitkileri Kongresi, 3-6 Ekim 1993, Ankara, 258-262 p. (In Turkish)

Pirlak L (1997). The relationship between the production, viability and germination capacity of pollen and fruit set in some cornelian cherry (Cornus mas L.) types. Bahçe 26:2128. (In Turkish)

Sass JE (1958). Botanical Microtechnique. 4 th Edition. Iowa State University Press, Ames, Iowa, USA.

TurkStat (2012). Turkish Statistical Institute. http://www.tuik. gov.tr/

Watson L, Dallwitz MJ (1992). The families of flowering plants: descriptions, illustrations, identification, and information retrieval. Available at: http://delta-intkey.com/ [accessed 1 June 2007]

WFE(2007).European Cornel. Wikipedia the free encyclopedia. http://en.wikipedia.org/wiki/European_Cornel

Wilkinson AM (1944). Floral anatomy of some species of cornus. Bulletion Torrey Botanical Club 71:276-301.

Xiang Q-Y, Shui Y-M, Murrell Z (2003). Cornus eydeana (Cornaceae) a new cornelian cherry from China-notes on systematic and evolution. Systematic Bot 28:757-764.

Xiang QY, Boufford DE (2005). Cornaceae (Dumortier) Dumortier. Flora of China 14:206-221.

Yalçinkaya E, Eti S (1999). Selection of cornelian cherry (Cornus mas L.) in some of the provinces of the Western Black Sea Region. Türkiye III. Bahçe Bitkileri Kongresi Bildirileri, 1417 Eylül 1999, Ankara, 781-786 p. (In Turkish) 